\title{
Genetics of cattle temperament and its impact on livestock production and breeding - a review
}

\author{
J. Friedrich ${ }^{1}$, B. Brand ${ }^{2}$, and M. Schwerin ${ }^{1,2}$ \\ ${ }^{1}$ Institute of Animal Science and Technology, University of Rostock, Rostock, Germany \\ ${ }^{2}$ Institute for Genome Biology, Leibniz Institute for Farm Animal Biology (FBN), Dummerstorf, Germany
}

Correspondence to: M. Schwerin (schwerin@fbn-dummerstorf.de)

Received: 6 June 2014 - Accepted: 13 November 2014 - Published: 4 March 2015

\begin{abstract}
Cattle temperament, which describes individual behaviour differences with regard to a stressor or environmental challenge, is known for its impact on working safety, adaptability to new housing conditions, animal productivity and for evaluation of animal welfare. However, successful use of temperament in animal breeding and husbandry to improve keeping conditions in general or animal welfare in particular, requires the availability of informative and reproducible phenotypes and knowledge about the genetic modulation of these traits. However, the knowledge about genetic influences on cattle temperament is still limited. In this review, an outline is given for the interdependence between production systems and temperament as well as for the phenotyping of cattle temperament based on both behaviour tests and observations of behaviour under production conditions. In addition, the use of temperament as a selection criterion is discussed.
\end{abstract}

\section{Introduction}

During the last several decades, new management systems have been introduced worldwide in cattle production, presenting new challenges for animals and farmers. In particular, the increasing automation of routine processes and growing herd sizes due to the intensification of livestock production limit the contact between cow and farmer (Raussi, 2003) and contributes to fear of humans and stressful events (Boissy et al., 2005). Since the ability of cattle to cope with external stimuli affects the susceptibility to stress (Jensen, 2006), stress from routine management processes, like the regrouping of a herd, can result in aggressiveness, increased locomotion and decreased productivity if coping strategies are insufficient (Bøe and Færevik, 2003). Increased stress has additionally been shown to affect physiological processes of the immune and reproductive system negatively (Burdick et al., 2011). Accordingly, cattle temperament, which describes "consistent behavioural and physiological differences observed between individuals in response to a stressor or environmental challenge" (Sutherland et al., 2012) is found to have a considerable impact on performance, reproduction, health and animal welfare. Temperament comprises be- havioural characteristics like shyness-boldness, explorationavoidance, activity, sociability and aggressiveness and is an important aspect of behaviour genetics (Réale et al., 2007).

Based on the theory that animal welfare comprises the animals' "state as regards its attempts to cope with its environment" (Broom, 1986) and with the evaluation of emotionally positive surroundings (Veissier et al., 2012), the selection for temperament types that are well suited for specific production systems is expected to improve productivity and overall animal welfare (Boissy et al., 2005; Ferguson and Warner, 2008). Animal welfare covers the physiological state, biological needs and furthermore the emotional condition of animals (von Keyserlingk et al., 2009). Criteria for the evaluation of animal welfare were introduced years ago by the concepts of the Farm Animal Welfare Council (FAWC, 1979) and by Bartussek et al. (2000), but in spite of different approaches, it is complicated to assess the emotional state of cattle since these concepts are mainly based on environmental factors. However, a novel approach, the Animal Welfare Assessment Protocol, introduced animal-based measurements including behaviour for assessing animal welfare (Welfare Quality $\left.{ }^{\circledR}, 2009\right)$. The assessment of cattle behaviour in certain situations could provide additional infor- 
mation on the physiological and emotional state of the animal overall, improving animal welfare evaluation.

Besides environmental influences, genetic factors are known to contribute to the development of the behaviour phenotype (Mormède, 2005). The possible genetic predisposition of temperament and the potential impact of temperament on cattle welfare and production traits has focussed attention on behavioural phenotyping and the opportunity of selection for temperament.

However, integrating cattle temperament in breeding programs is difficult. Temperament is assumed to be multidimensional, and due to the complexity of behavioural traits there is no single objective measurement that is able to capture all behavioural characteristics (Réale et al., 2007). In addition, Oltenacu and Broom (2010) found a conceivable competitive relationship between the genetic selection for dairy production and adaptability due to limited physiological resources, resulting in poorer adaptability by selection for milk yields. Furthermore, Grandin (1994) discussed that the masking of unfavourable behavioural traits like nervousness, flightiness or excitability by adaption to the human-created environment of livestock production hinders the selection for behavioural traits like temperament. One possibility for overcoming these problems is the analysis of the genetic background of cattle behaviour, which could contribute to the successful integration of temperament in breeding programs by the use of temperament associated markers (marker-assisted selection or genomic selection) and further help to evaluate the correlation between temperament and performance. The most important prerequisite to identify genetic loci affecting temperament is the development of distinct informative and reproducible phenotypes characterizing different temperament types.

\section{Phenotyping cattle temperament}

\subsection{Cattle temperament and production systems}

Particular experiences, especially early ones, are important in the development of temperament in cattle. On average, young cattle were observed to be more temperamental than older cattle (Voisinet et al., 1997; Lanier et al., 2000) and with ageing, cattle behaviour was found to be more consistent over time (Gibbons et al., 2011; Haskell et al., 2012). These modulations of behaviour through individual experiences and therefore through ageing are assumed to evolve from changes in the reactivity of the nervous system (Grandin and Dessing, 1998). The graduate adaption to repeated external stimuli is referred to as habituation (Cyr and Romero, 2009). In livestock production, habituation is mainly determined by the adaptability to human-made environments and the frequency of human-animal contact overall, depending on the production system. Extensively kept cattle, for example, are only occasionally handled and are therefore less approachable than intensively housed beef or dairy cattle (Le Neindre et al., 1996). As a consequence of the adaption and selection for different production and housing systems, a large variability in temperament exists today in farm animals, resulting from differences in reactions towards human contact and new surroundings (Hopster, 1998; Sutherland et al., 2012). Fear is considered one of the main psychological factors underlying temperament traits in general, and in particular, fear of humans affects the human-animal relationship considerably (Adamczyk et al., 2013). When humans were involved in behaviour tests, it could be observed that fearfulness was more evident in comparison to tests without human presence (Mazurek et al., 2011). The degree of fearfulness, or avoidance, of humans is indicated by the flight distance or flight speed that is known to depend on the frequency and quality of human-cattle habituation (Waiblinger et al., 2003; Schütz et al., 2012) and can be measured when an animal flees to avoid human contact. Besides individual experiences and ageing, the influence of sex on cattle temperament is discussed. Some beef cattle studies documented that cows had higher temperament scores than steers (Voisinet et al., 1997; Gauly et al., 2002; Hoppe et al., 2010). Just as the production system promotes certain behavioural characteristics, animalspecific temperament can likewise affect relevant parameters in livestock production. Docility in cows, for example, was observed to affect reproduction traits positively, including the calving rate, the age at first observed oestrus (Phocas et al., 2006) and conception rates (Cooke et al., 2011). Furthermore, a negative correlation was reported between fear of humans and milk yield (Hemsworth et al., 2000), explaining up to $19 \%$ of the milk yield variances between farms observed in the study of Breuer et al. (2000). The dynamics of the hormone oxytocin have been widely analysed as a possible explanation for the correlation between temperament and milk performance. Bruckmaier and Blum (1998) summed up that the release of oxytocin may be repressed by the central nervous system due to increased levels of $\beta$-endorphin and cortisol when cows were milked in novel environments. Rushen et al. (2001) documented lower plasma oxytocin concentrations in unfamiliar milking parlours confirming a negative effect of novelty on milk production, whereas Sutherland et al. (2012) found higher oxytocin concentrations and a drop in milk yield after milking in novel environments. They discussed variations in the activation of the sympathetic nervous system as causal physiological mechanisms for disturbances in milk letdown by peripheral inhibition of oxytocin effects, as it is suggested by Van Reenen et al. (2002). In a study of Orbán et al. (2011), no correlation between milk yield and temperament could be detected, but calmer cattle had lower somatic cell counts.

In beef cattle, negative side effects of temperament on the average daily weight gain, live weight and meat quality were reported in various studies (Voisinet et al., 1997; Gauly et al., 2001; Petherick et al., 2002; King et al., 2006; Nkrumah et al., 2007; Hall et al., 2011; Vetters et al., 2013). In Bos taurus steers, for example, docility resulted in up to $0.19 \mathrm{~kg}$ 
higher average daily weight gains (Voisinet et al., 1997). The individual temperament is discussed to affect weight gains through influencing the feed conversion efficiency (Petherick et al., 2002) and inducing differences in feed intake and time spent eating (Cafe et al., 2011b). In addition differences in the susceptibility to stress during slaughter were shown to result in variances regarding meat quality. Calm animals were observed to have significantly higher postmortem $\mathrm{pH}$ values (King et al., 2006) and more tender meat (Hall et al., 2011). Magolski et al. (2013) tried to explain the mechanisms behind the correlation of temperament and beef tenderness by analysing the association between protein degradation, calpain system activity and temperament but no significant explanatory relationship could be identified. Despite more and more studies on a possible correlation between cattle behaviour and production traits, inconsistent findings illustrate the demand for further research and standardized tests to elucidate the underlying mechanisms.

\subsection{Measuring the behavioural phenotype in cattle}

In cattle, many approaches exist for measuring behaviour. A detailed overview about different behaviour test conditions and their use in farm animals is given by Canario et al. (2013). Behaviour tests are often adapted from behavioural studies of laboratory rodents and can be distinguished based on the type of test (restrained or nonrestrained), the data assessment (during routine handling or specific test conditions) and the type of measured trait (qualitative or quantitative). One example is the open-field test, which is well documented and frequently used in model animals. The open-field test can be classified as a non-restrained test where the cow is free to move within a defined testing area. Kilgour (1975) introduced the open-field test for the assessment of temperament in dairy cows for its several advantages which are simple construction and the creation of a completely new environment, allowing the testing of numerous behavioural characteristics, like reactivity towards novelty and social isolation. Critical aspects of behaviour assessments in artificial test situations are the time and space requirements to conduct the behaviour test. Therefore behaviour is commonly evaluated during routine handling processes since they are not highly time and space consuming. In dairy cattle, for example, behavioural assessment is usually conducted by scoring temperament for nervousness, aggressiveness or docility during milking by farmers or milking technicians (Dickson et al., 1970; Hiendleder et al., 2003). However, in beef cattle, scoring during weighing is a frequent test for determining temperament. When cattle's opportunities to move are limited, as in a chute during weighing and milking, this is referred to as a restrained test (Burrow, 1997), the main advantage of which is safe application for the handler (Boivin et al., 1992). A restraint test is able to quantify characteristics like the chute score or flight speed (exit velocity) to evaluate the temperament in response to a short time fixation, e.g. in a squeeze chute (Black et al., 2013; Vetters et al., 2013; Magolski et al., 2013). During fixation, the number of movements is suggested to be as most promising trait for selection of beef cattle temperament in Benhajali et al. (2010). In their study, the number of movements during weighing, recorded between 180 and 280 days of age, had the highest heritability $\left(h^{2}=0.31 \pm 0.10\right)$ in comparison to recorded movements when exposed to a stationary human, with a high number of steps implying more agitated animals.

Also challenging, but essential for investigating behaviour in cattle, is the interpretation of behavioural traits which are usually expressed by only a few animals (Brouček et al., 2008). Such traits, like vocalization or escape events (out of the testing area), are highly informative but complicate statistical evaluation. The determination of the behaviour phenotype can be done qualitatively by temperament scoring or quantitatively by measurements of objective parameters like time spent running, number of escapes, flight time or vocalization events (Watts et al., 2001; Gutiérrez-Gil et al., 2008; Cafe et al., 2011b). In general, the use of automatic measurement integrated into routine processes, for example weighing or milking, is desired in the determination of cattle temperament with regard to time-management and objectivity. In various studies, it could be shown that the determination of behavioural traits or temperament was successful using automated detection. König et al. (2006) recorded the frequency of voluntary entries into an automated milking system in dairy cows and proposed this trait as breeding criterion for cattle behaviour and Schwartzkopf-Genswein et al. (2012) suggested two electronic measuring systems for the prediction of cattle temperament. In their study, the assessments of strain gauges and accelerometers for the movements of cattle in a squeeze chute were highly correlated to subjective temperament scores.

Depending on the procedure of behaviour assessment, specific behaviours are stimulated, for example, exploratory behaviour in an open-field test or fear of humans in humanapproach tests (Réale et al., 2007). This specificity hinders the comparability between different testing conditions as it was shown for a human approachability and novel stimuli tests in Gibbons et al. (2009). Although temperament scoring is subjectively due to the perception of the observer, but usually based on experimental protocols, it could be shown that temperament scores were favourably correlated to quantitative records (Schwartzkopf-Genswein et al., 2012). For increasing the accuracy of the determined phenotype or temperament type, the combination of behaviour records and physiological and endocrinological parameters are used in behaviour studies. Measurements of cortisol and heart rate are often used to measure the activity of the hypothalamicpituitary-adrenal axis and sympatho-adrenal medullary system as supplementary indicators for the stress response in cattle (Grignard et al., 2001; King et al., 2006; Curley Jr. et al., 2008; Burdick et al., 2010; Cafe et al., 2011a). Higher heart rates and cortisol levels indicate more excitable or tem- 
peramental cattle. Furthermore, Burdick et al. (2010) found a positive correlation between temperament and rectal temperature. A rather rarely applied approach for evaluating behaviour in cattle was used in the study of Core et al. (2009). They found a highly significant correlation, ranging from 0.67 to 0.95 , between the eye-white percentage and temperament scores assessed in a chute test in beef cattle. Besides the analysis of behavioural traits and physiological parameters, the additional consideration of genetic information could help to discriminate between behaviour phenotypes and reveal differences and commonalities between the particular applied test conditions and measured behaviours.

\section{Genetic variances affecting temperament in cattle}

\subsection{Genetic background of cattle temperament}

Today, the genetic background of cattle temperament is generally accepted. A first indication for a genetic predisposition and an essential process leading to the development of the contemporary livestock behaviour is found in the domestication of cattle ancestors beginning 10500 years ago. At that time, animals were selected for their adaptability to man-made environments and their reactivity towards humans. Therefore, tameness and adaptability can be seen as main fitness-determining factors (Price, 1999) which are assumed to be under genetic control (Baker et al., 2001). Further evidence for a genetic predisposition of cattle behaviour are in the observed variances in inter-breed temperament. These differences can be attributed to the selection for specific production systems as well as housing and climatic conditions. In general, Bos indicus breeds were found to be more excitable than Bos taurus breeds (Voisinet et al., 1997). Dairy cattle showed a higher approachability than beef cattle (Murphey et al., 1980) and were more reactive to sudden noises during cattle auctions (Lanier et al., 2000). Moreover, numerous behaviour studies were conducted for different beef breeds enabling a temperament ranking from more calm breeds like Herford and Angus to breeds that are more temperamental like German Simmental or Charolais (Morris et al., 1994; Gauly et al., 2002; Hoppe et al., 2010).

Estimated heritabilities for temperament, which are rather low or moderate, indicate a lower proportion of a genetic predisposition on the phenotypic variance. In Holstein cows, early estimates for milking temperament ranged from 0.11 to 0.17 (Lawstuen et al., 1988; Visscher and Goddard, 1995; Rupp and Boichard, 1999; Schrooten et al., 2000). In a more recent study, heritability reached values of 0.13 and 0.25 for milking temperament and milking speed in Canadian Holstein cattle (Sewalem et al., 2011). The estimated heritability for temperament traits in beef cattle is on average higher but with a greater margin, ranging from 0.11 to 0.61 , presumably due to different behaviour phenotypes and sample sizes (Burrow, 2001; Gauly et al., 2001; Phocas et al., 2006; Nkrumah et al., 2007; Hoppe et al., 2010). Besides the ac- ceptance of genetic variances contributing to the modulation of behaviour, current knowledge about genotype-phenotype interactions is still limited. One reason, the complexity of behavioural traits, has been discussed; the complexity is often distinguished by different genetic loci and therefore expected to be polygenic traits with quantitative inheritance patterns (Jensen, 2006).

The genetic impact on behaviour is not direct, but results from a complex response network of neurophysiological and structural factors, like hormones and proteins, themselves products of indirect genetic effects (Johnston and Edwards, 2002). It is assumed that proteins involved in this process have rather general functions, like protein kinases (Price, 2008). Protein kinase C, for example, was recently identified as a regulator of mood-related behaviours in rats (Abrial et al., 2013) and protein kinase $\mathrm{G}$ is discussed to affect diverse behaviours in different species (reviewed in Reaume and Sokolowski, 2009). Important neurotransmitters that contribute to the development of behaviour are assumed to arise from the serotonergic or catecholaminergic system (Mormède, 2005). A frequently investigated physiological pathway with a high inter-individual variability that can modulate behavioural characteristics is the stress response mediated through the hypothalamic-pituitary-adrenal (HPA) axis. HPA axis activity and aggressive behaviour were recently reported to be associated with two single nucleotide polymorphisms (SNPs) in pigs (Muráni et al., 2010). Likewise in cattle, parameters of the HPA axis activity were shown to be correlated to cattle temperament. Temperamental heifers were found to have higher baseline cortisol concentrations than calmer animals (Curley Jr. et al., 2008). A detailed investigation of the genetic correlation between behaviour and HPA axis parameters could be a valuable approach to identify relevant pathways and physiological responses resulting from the genetic predisposition of temperament.

In the discussion about genetic influences on behaviour, attention must also be paid to numerous environmental factors which are external stimuli for the expression of behaviour. As a consequence of substantial environmental effects on behaviour, genes affecting temperament in cattle are noted to have smaller effect sizes and thus explain a lower proportion of the phenotypic variance in comparison to genetic loci, which are associated with production traits (GutiérrezGil et al., 2008). Flint (2003) found that in laboratory rodents merely $10 \%$ of behaviour differences are caused by genes. Nevertheless, genes and environment should not be considered as antagonistic factors in the regulation of behaviour, but rather as interactive (Bendesky and Bargmann, 2011). However, the approach of nature and nurture in the context of behaviour is still debated as controversial in the literature. 


\subsection{Genomic regions associated with temperament traits}

Genetic markers for behavioural characteristics have already been identified in different livestock species, for example for feather picking in hens (Flisikowski et al., 2009) and for different behavioural traits in pigs (Reiner et al., 2009). In cattle, the results of previous studies have provided further proof for a genetic disposition of behaviour and moreover confirm the assumption that specific behavioural traits are influenced by different genomic regions (Schmutz et al., 2001; GutiérrezGil et al., 2008). In the following, the important analyses related to cattle temperament and genetics are summarized.

In dairy cattle, research about the genetic correlation of behaviour has been focussed on milking temperament primarily. Spelman et al. (1999) assessed subjective temperament scores for New Zealand Holstein-Friesian and Jersey cows during milking for genetic analysis, but no QTL (quantitative trait loci) for milking adaptability could be identified. Likewise, Schrooten et al. (2000) found no QTL correlated with temperament during milking in Holstein-Friesian cattle, but three genomic regions with suggestive linkage for milking speed where located on chromosomes 2, 3 and 23. In contrast, Hiendleder et al. (2003) detected four QTL for behaviour during milking on the chromosomes 5, 18, and 29 in the same breed. Additionally, these QTL were in close proximity to the QTL identified for milking speed in the same study, indicating that these might be single QTL affecting both traits. In further QTL mapping studies, the behaviour phenotypes were assessed during specific test conditions and other routine handling procedures. Five microsatellite markers were identified to be linked to flight distance towards unfamiliar humans in Limousin and Jersey cows by Fisher et al. (2001). Two more polymorphisms were associated with the cortisol concentration in urine and one putative marker was detected for plasma cortisol level as a response to stress before slaughtering. In a crossbred population of Brahman and Angus cattle, behaviour was scored for aggressiveness, nervousness, flightiness, gregariousness and overall temperament during weaning and slaughtering. QTL for these scores were found on BTA1, 4, 8, 9, 16 and 18 (Wegenhoft, 2005). Boldt (2008) analysed the same experimental population confirming the temperament associated QTL on BTA8 and found additional QTL on BTA3, 6, 12, 26 and 29 by the use of different statistical approaches. Gutiérrez-Gil et al. (2008) detected 29 QTL, distributed over 17 chromosomes in a Holstein-Charolais crossbreed population. These genomic regions were significantly associated with traits like frequency of vocalization, flight distance or standing at alert that were recorded during a flight from a feeder and a social separation test. In some of these behaviour related linkage studies, dominance effects of QTL were reported (Wegenhoft, 2005; Gutiérrez-Gil et al., 2008). Aberrations concerning rearing conditions and cattle breeds (Hoppe et al., 2010) as well as different evaluations of behaviour pheno- types and different marker densities complicate the comparability between studies and must be taken into account. Nevertheless, overlapping QTL were found between the studies, especially on BTA29 (Hiendleder et al., 2003; Gutiérrez-Gil et al., 2008; Glenske et al., 2011).

\section{Candidate genes}

Another approach for revealing molecular pathways which modulate behaviour is the investigation of functional candidate genes that are associated with behavioural characteristics underlying temperament in other species (reviewed in Bendesky and Bargmann, 2011) or of positional candidate genes that are located in QTL for behavioural traits. In cattle, putative candidate genes that affect behavioural traits in distinct situations such as oestrus and feeding behaviour have been reported (Nkrumah et al., 2005; Kommadath et al., 2011; Hulsegge et al., 2013). One example for a positional and functional candidate gene for cattle temperament is the tyrosinase gene $(T Y R)$, which is generally known for its function in the dilution of coat colour in cattle (Schmidtz et al., 2001), and is located in a QTL for temperament during milking on BTA29 (Hiendleder et al., 2003). Tyrosinase catalyses reactions in the dopamine metabolism and is assumed to be involved in the appearance of Parkinson's disease in humans (Hasegawa, 2010). Other genes involved in dopamine metabolism have been suggested as further functional candidate genes because the neurotransmitter dopamine itself is associated with behavioural traits and diseases in different species. A prominent candidate gene, the dopamine receptor D4 gene (DRD4) has been associated with behavioural traits like novelty seeking and curiosity in humans and different animals (Bailey et al., 2007; Munafò et al., 2008; Korsten et al., 2010). In cattle, DRD4 can be mapped to the distal part of BTA29 (Glenske et al., 2011), but no QTL or direct association for temperament in cattle have been identified in this region so far. Another widely discussed functional candidate gene is the monoamine oxidase $\mathrm{A}(M A O A)$ gene, which degrades catecholamines like serotonin, norepinephrine and dopamine (Shih et al., 1999). Lühken et al. (2010) analysed the structure of the MAO A gene in German Angus and Simmental cattle and identified five SNPs in the coding region but none of these polymorphisms were significantly associated with behaviour scores that were assessed during tethering, weighing and social separation tests. Further positional candidate genes that were located in QTL regions associated with temperament are the cannabinoid receptor $(C N R I)$ gene on BTA9 (Schmutz et al., 2001), the regulator of G-protein signalling 2 (RGS2) gene, the plexin A2 (PLXA2) gene on BTA16 and the prolactin precursor receptor $(P R L-R)$ gene on BTA20 (Gutiérrez-Gil et al., 2008), but no further investigation of these candidate genes have been performed in cattle thus far. 


\section{Perspective and challenges of behaviour genetics in cattle}

Increasing attention has been paid to cattle temperament in livestock production for its benefit to working safety, adaptability to new housing conditions, animal welfare and production. Boissy et al. (2005) even considered the importance of selection for adaptability as equal in importance to the quality of housing systems with regard to animal welfare. As a consequence, breeding for cattle behaviour has been intensively discussed. In some countries, milking temperament of dairy cattle is already integrated as a selection index into breeding programs (reviewed in Adamczyk et al., 2013), whereas in beef cattle, temperament is indeed recognized as an important trait for economic efficiency and frequently assessed, but its use as a selection index is uncommon (Sant'Anna et al., 2013). Reasons for this nonconsideration are the possible competitive genetic relationship between temperament and production traits (Oltenacu and Broom, 2010) and complex behaviour evaluations.

To date considerable insights into behaviour genetics from candidate genes to key neurological pathways have been given for other species (reviewed in Bendesky and Bargmann, 2011), but information on cattle are limited to QTL mapped for behaviour, which still need confirmation and functional approval. To overcome this lack of information, further research is needed taking new technologies, such as microarrays, next-generation sequencing and metabolomics, into account. In addition, objective and informative methods for the assessment of cattle temperament are needed, which can then be standardized for use in cattle husbandry and breeding. In general, the behaviour measurement should have adequate heritability, a high level of reproducibility, simple application and should include handling conditions since approachability and fear of humans are important aspects of cattle behaviour.

Acknowledgements. This work was supported by the German Federal Ministry of Education and Research (BMBF) in the context of PHENOMICS network (grant no. 0315536A).

Edited by: K. Wimmers

Reviewed by: three anonymous referees

\section{References}

Abrial, E., Etievant, A., Bétry, C., Scarna, H., Lucas, G., Haddjeri, N., and Lambás-Señas, L.: Protein kinase C regulates moodrelated behaviors and adult hippocampal cell proliferation in rats, Prog. Neuropsychoph., 43, 40-48, 2013.

Adamczyk, K., Pokorska, J., Makulska, J., Earley, B., and Mazurek, M.: Genetic analysis and evaluation of behavioural traits in cattle, Livest. Sci., 154, 1-12, 2013.

Bailey, J. N., Breidenthal, S. E., Jorgensen, M. J., McCracken, J. T., and Fairbanks, L. A.: The association of DRD4 and novelty seeking is found in a nonhuman primate model, Psychiat. Genet., 17, 23-27, 2007.

Baker, B. S., Taylor, B. J., and Hall, J. C.: Are Complex Behaviors Specified by Dedicated Regulatory Genes? Reasoning from Drosophila, Cell, 105, 13-24, 2001.

Bartussek, H., Leeb, C., and Held, S.: Animal needs index for cattle. ANI 35L/2000-cattle, Federal Research Institute for Agriculture in Alpine Regions BAL Gumpenstein, Irdning, Austria, 2000.

Bendesky, A. and Bargmann, C. I.: Genetic contributions to behavioural diversity at the gene-environment interface, Nat. Rev. Genet., 12, 809-820, 2011.

Benhajali, H., Boivin, X., Sapa, J., Pellegrini, P., Boulesteix, P., Lajudie, P., and Phocas, F.: Assessment of different on-farm measures of beef cattle temperament for use in genetic evaluation, J. Anim. Sci., 88, 3529-3537, 2010.

Black, T. E., Bischoff, K. M., Mercadante, V. R. G., Marquezini, G. H. L., DiLorenzo, N., Chase Jr., C. C., Coleman, S. W., Maddock, T. D., and Lamb, G. C.: Relationships among performance, residual feed intake, and temperament assessed in growing beef heifers and subsequently as 3-year-old, lactating beef cows, J. Anim. Sci., 91, 2254-2263, 2013.

Bøe, K. E. and Færevik, G.: Grouping and social preferences in calves, heifers and cows, Appl. Anim. Behav. Sci., 80, 175-190, 2003.

Boissy, A., Fisher, A. D., Bouix, J., Hinch, G. N., and Le Neindre, P.: Genetics of fear in ruminant livestock, Livest. Prod. Sci., 93, 23-32, 2005.

Boivin, X., Le Neindre, P., Chupin, J. M., Garel, J. P., and Trillat, G.: Influence of breed and early management on ease of handling and open-field behaviour of cattle, Appl. Anim. Behav. Sci., 32, 313-323, 1992.

Boldt, C. R.: A study of cattle disposition: Exploring QTL associated with temperament, Senior honors thesis, Texas A\&M University, College Station, TX, USA, 2008.

Breuer, K., Hemsworth, P. H., Barnett, J. L., Matthews, L. R., and Coleman, G. J.: Behavioural response to humans and the productivity of commercial dairy cows, Appl. Anim. Behav. Sci., 66, 273-288, 2000.

Broom, D. M.: Indicators of poor welfare, Br. Vet. J., 142, 524-526, 1986.

Brouček, J., Uhriničať, M., Šoch, M., and Kišac, P.: Genetics of behaviour in cattle, Slovak. J. Anim. Sci., 41, 166-172, 2008.

Bruckmaier, R. M. and Blum, J. W.: Oxytocin Release and Milk Removal in Ruminants, J. Dairy Sci., 81, 939-949, 1998.

Burdick, N. C., Carroll, J. A., Hulbert, L. E., Dailey, J. W., Willard, S. T., Vann, R. C., Welsh Jr., T. H., and Randel, R. D.: Relationships between temperament and transportation with rectal temperature and serum concentrations of cortisol and epinephrine in bulls, Livest. Sci., 129, 166-172, 2010.

Burdick, N. C., Randel, R. D., Carroll, J. A., and Welsh Jr., T. H.: Interactions between Temperament, Stress, and Immune Funtion in Cattle, Int. J. Zool., 2011, Article ID 373197, 9 pages, 2011.

Burrow, H. M.: Measurements of temperament and their relationships with performance traits of beef cattle, Anim. Breed. Abstr., 65, 477-495, 1997.

Burrow, H. M.: Variances and covariances between productive and adaptive traits and temperament in a composite breed of tropical beef cattle, Livest. Prod. Sci., 70, 213-233, 2001. 
Cafe, L. M., Robinson, D. L., Ferguson, D. M., Geesink, G. H., and Greenwood, P. L.: Temperament and hypothalamic-pituitaryadrenal axis function are related and combine to affect growth, efficiency, carcass, and meat quality traits in Brahman steers, Domest. Anim. Endocrinol., 40, 230-240, 2011 a.

Cafe, L. M., Robinson, D. L., Ferguson, D. M., McIntyre, B. L., Geesink, G. H., and Greenwood, P. L.: Cattle temperament: Persistence of assessments and associations with productivity, efficiency, carcass and meat quality traits, J. Anim. Sci, 89, 14521465, 2011b.

Canario, L., Mignon-Grasteau, S., Dupont-Nivet, M., and Phocas, F.: Genetics of behavioural adaptation of livestock to farming conditions, Animal, 7, 357-377, 2013.

Cooke, R. F., Bohnert, D. W., Meneghetti, M., Losi, T. C., and Vasconcelos, J. L. M.: Effects of temperament on pregnancy rates to fixed-time AI in Bos indicus beef cows, Livest. Sci., 142, 108$113,2011$.

Core, S., Widowski, T., Mason, G., and Miller, S.: Eye white percentage as a predictor of temperament in beef cattle, J. Anim. Sci., 87, 2168-2174, 2009.

Curley Jr., K. O., Neuendorff, D. A., Lewis, A. W., Cleere, J. J., Welsh Jr., T. H., and Randel, R. D.: Functional characteristics of the bovine hypothalamic-pituitary-adrenal axis vary with temperament, Horm. Behav., 53, 20-27, 2008.

Cyr, N. E. and Romero, L. M.: Identifying hormonal habituation in field studies of stress, Gen. Comp. Endocrinol., 161, 295-303, 2009.

Dickson, D. P., Barr, G. R., Johnson, L. P., and Wieckert, D. A.: Social Dominance and Temperament in Holstein Cows, J. Dairy. Sci., 53, 904-907, 1970.

FAWC: Press statement from the Farm Animal Welfare Council, http://webarchive.nationalarchives.gov.uk/20121007104210/ http://www.fawc.org.uk/pdf/fivefreedoms1979.pdf (last access: 15 November 2014), 1979.

Ferguson, D. M. and Warner, R. D.: Have we underestimated the impact of pre-slaughter stress on meat quality in ruminants?, Meat. Sci., 80, 12-19, 2008.

Fisher, A. D., Morris, C. A., Matthews, L. R., Pitchford, W. S., and Bottema, C. D. K.: Handling and stress response traits in cattle: identification of putative genetic markers, in: Proc 35th Intern Conf ISAE, University of Ccalifornia Davis, Davis, CA, USA, p. $100,2001$.

Flint, J.: Analysis of quantitative trait loci that influence animal behavior, J. Neurobiol., 54, 46-77, 2003.

Flisikowski, K., Schwarzenbacher, H., Wysocki, M., Weigend, S., Preisinger, R., Kjaer, J. B., and Fries, R.: Variation in neighbouring genes of the dopaminergic and serotonergic systems affects feather pecking behaviour of laying hens, Anim. Genet., 40, 192199, 2009.

Gauly, M., Mathiak, H., Hoffmann, K., Kraus, M., and Erhardt, G.: Estimating genetic variability in temperamental traits in German Angus and Simmental cattle, Appl. Anim. Behav. Sci., 74, 109119, 2001.

Gauly, M., Mathiak, H., and Erhardt, G.: Genetic background of behavioural and plasma cortisol response to repeated short-term separation and tethering of beef calves, J. Anim. Breed. Genet., $119,379-384,2002$.
Gibbons, J., Lawrence, A., and Haskell, M.: Responsiveness of dairy cows to human approach and novel stimuli, Appl. Anim. Behav. Sci., 116, 163-173, 2009.

Gibbons, J. M., Lawrence, A. B., and Haskell, M. J.: Consistency of flight speed and response to restraint in a crush in dairy cattle, Appl. Anim. Behav. Sci., 131, 15-20, 2011.

Glenske, K., Prinzenberg, E. M., Brandt, H., Gauly, M., and Erhardt, G.: A chromosome-wide QTL study on BTA29 affecting temperament traits in German Angus beef cattle and mapping of DRD4, Animal, 5, 195-197, 2011.

Grandin, T.: Solving livestock handling problems, Vet. Med., 89, 989-998, 1994.

Grandin, T. and Dessing, M. J.: Behavioral genetics and animal science, in: Genetics and the behavior of domestic animals, edited by: Grandin, T., Academic Press, San Diego, CA, USA, 1-30, 1998.

Grignard, L., Boivin, X., Boissy, A., and Le Neindre, P.: Do beef cattle react consistently to different handling situations?, Appl. Anim. Behav. Sci., 71, 263-276, 2001.

Gutiérrez-Gil, B., Ball, N., Burton, D., Haskell, M., Williams, J. L., and Wiener, P.: Identification of Quantitative Trait Loci Affecting Cattle Temperament, J. Hered., 99, 629-638, 2008.

Hall, N. L., Buchanan, D. S., Anderson, V. L., Ilse, B. R., Carlin, K. R., and Berg, E. P.: Working chute behavior of feedlot cattle can be an indication of cattle temperament and beef carcass composition and quality, Meat. Sci., 89, 52-57, 2011.

Hasegawa, T.: Tyrosinase-Expressing Neuronal Cell Line as in Vitro Model of Parkinson's Disease, Int. J. Mol. Sci., 11, 1082-1089, 2010.

Haskell, M. J., Bell, D. J., and Gibbons, J. M.: Is the response to humans consistent over productive life in dairy cows?, Anim. Welfare, 21, 319-324, 2012.

Hemsworth, P. H., Coleman, G. J., Barnett, J. L., and Borg, S.: Relationships between human-animal interactions and productivity of commercial dairy cows, J. Anim. Sci., 78, 2821-2831, 2000.

Hiendleder, S., Thomsen, H., Reinsch, N., Bennewitz, J., LeyheHorn, B., Looft, C., Xu, N., Medjugorac, I., Russ, I., Kühn, C., Brockmann, G. A., Blümel, J., Brenig, B., Reinhardt, F., Reents, R., Averdunk, G., Schwerin, M., Förster, M., Kalm, E., and Erhardt, G.: Mapping of QTL for Body Conformation and Behavior in Cattle, J. Hered., 94, 496-506, 2003.

Hoppe, S., Brandt, H. R., König, S., Erhardt, G., and Gauly, M.: Temperament traits of beef calves measured under field conditions and their relationships to performance, J. Anim. Sci., 88, 1982-1989, 2010.

Hopster, H.: Coping strategies in dairy cows, Doctoral thesis, Agricultural University Wageningen, Wageningen, Netherlands, 1998.

Hulsegge, I., Woelders, H., Smits, M., Schokker, D., Jiang, L., and Sørensen, P.: Prioritization of candidate genes for cattle reproductive traits, based on protein-protein interactions, gene expression, and text-mining, Physiol. Genomics, 45, 400-406, 2013.

Jensen, P.: Domestication - From behaviour to genes and back again, Appl. Anim. Behav. Sci., 97, 3-15, 2006.

Johnston, T. D. and Edwards, L.: Genes, interactions, and the development of behavior, Psychol. Rev., 109, 26-34, 2002.

Kilgour, R.: The open-field test as an assessment of the temperament of dairy cows, Anim. Behav., 23, 615-624, 1975. 
King, D. A., Schuehle Pfeiffer, C. E., Randel, R. D., Welsh Jr., T. H., Oliphint, R. A., Baird, B. E., Curley Jr., K. O., Vann, R. C., Hale, D. S., and Savell, J. W.: Influence of animal temperament and stress responsiveness on the carcass quality and beef tenderness of feedlot cattle, Meat. Sci., 74, 546-556, 2006.

Kommadath, A., Woelders, H., Beerda, B., Mulder, H. A., de Wit, A. A. C., Veerkamp, R. F., te Pas, M. F. W., and Smits, M. A.: Gene expression patterns in four brain areas associate with quantitative measure of estrous behavior in dairy cows, BMC Genomics, 12, 200, 2011.

König, S., Köhn, F., Kuwan, K., Simianer, H., and Gauly, M.: Use of Repeated Measures Analysis for Evaluation of Genetic Background of Dairy Cattle Behavior in Automatic Milking Systems, J. Dairy Sci., 89, 3636-3644, 2006.

Korsten, P., Mueller, J. C., Hermannstädter, C., Bouwman, K. M., Dingemanse, N. J., Drent, P. J., Liedvogel, M., Matthysen, E., van Oers, K., van Overveld, T., Patrick, S. C., Quinn, J. L., Sheldon, B. C., Tinbergen, J. M., and Kempenaers, B.: Association between DRD4 gene polymorphism and personality variation in great tits: a test across four wild populations, Mol. Ecol., 19, 832-843, 2010.

Lanier, J. L., Grandin, T., Green, R. D., Avery, D., and McGee, K.: The relationship between reaction to sudden, intermittent movements and sounds and temperament, J. Anim. Sci., 78, 14671474, 2000.

Lawstuen, D. A., Hansen, L. B., and Steuernagel, G. R.: Management Traits Scored Linearly by Dairy Producers, J. Dairy Sci., 71, 788-799, 1988.

Le Neindre, P., Boivin, X., and Boissy, A.: Handling of extensively kept animals, Appl. Anim. Behav. Sci., 49, 73-81, 1996.

Lühken, G., Glenske, K., Brandt, H., and Erhardt, G.: Genetic variation in monoamine oxidase $\mathrm{A}$ and analysis of association with behaviour traits in beef cattle, J. Anim. Breed. Genet., 127, 411418, 2010.

Magolski, J. D., Berg, E. P., Hall, N. L., Anderson, V. L., Keller, W. L., Jeske, T. M., and Maddock Carlin, K. R.: Evaluation of feedlot cattle working chute behavior relative to temperament, tenderness, and postmortem proteolysis, Meat. Sci., 95, 92-97, 2013.

Mazurek, M., McGee, M., Crowe, M. A., Prendiville, D. J., Boivin, X., and Earley, B.: Consistency and stability of behavioural fear responses of heifers to different fear-eliciting situations involving humans, Appl. Anim. Behav. Sci., 131, 21-28, 2011.

Mormède, P.: Molecular genetics of behaviour: research strategies and perspectives for animal production, Livest. Prod. Sci., 93, 15-21, 2005.

Morris, C. A., Cullen, N. G., Kilgour, R., and Bremner, K. J.: Some genetic factors affecting temperament in Bos taurus cattle, New Zeal. J. Agr. Res., 37, 167-175, 1994.

Munafò, M. R., Yalcin, B., Willis-Owen, S. A., and Flint, J.: Association of the Dopamine D4 Receptor (DRD4) Gene and Approach-Related Personality Traits: Meta-Analysis and New Data, Biol. Psychiat., 63, 197-206, 2008.

Muráni, E., Ponsuksili, S., D’Eath, R. B., Turner, S. P., Kurt, E., Evans, G., Thölking, L., Klont, R., Foury, A., Mormède, P., and Wimmers, K.: Association of HPA axis-related genetic variation with stress reactivity and aggressive behaviour in pigs, BMC Genetics, 11, 74, 2010.
Murphey, R. M., Moura Duarte, F. A., Torres Penedo, M. C.: Approachability of Bovine Cattle in Pastures: Breed Comparisons and a Breed x Treatment Analysis, Behav. Genet., 10, 171-181, 1980.

Nkrumah, J. D., Li, C., Yu, J., Hansen, C., Keisler, D. H., and Moore, S. S.: Polymorphisms in the bovine leptin promoter associated with serum leptin concentration, growth, feed intake, feeding behavior, and measures of carcass merit, J. Anim. Sci., 83, 20-28, 2005.

Nkrumah, J. D., Crews Jr., D. H., Basarab, J. A., Price, M. A., Okine, E. K., Wang, Z., Li, C., and Moore, S. S.: Genetic and phenotypic relationships of feeding behavior and temperament with performance, feed efficiency, ultrasound, and carcass merit of beef cattle, J. Anim. Sci., 85, 2382-2390, 2007.

Oltenacu, P. A. and Broom, D. M.: The impact of genetic selection for increased milk yield on the welfare of dairy cows, Anim. Welfare, 19, 39-49, 2010.

Orbán, M., Gaál, K. K., Pajor, F., Szentléleki, A., Póti, P., Tözsér, J., and Gulyás, L.: Effect of temperament of Jersey and Holstein Friesian cows on milk production traits and somatic cell count, Arch. Tierz., 54, 594-599, 2011.

Petherick, J. C., Holroyd, R. G., Doogan, V. J., and Venus, B. K.: Productivity, carcass and meat quality of lot-fed Bos indicus cross steers grouped according to temperament, Aust. J. Exp. Agric., 42, 389-398, 2002.

Phocas, F., Boivin, X., Sapa, J., Trillat, G., Boissy, A., and Le Neindre, P.: Genetic correlations between temperament and breeding traits in Limousin heifers, Anim. Sci., 82, 805-811, 2006.

Price, E. O.: Behavioral development in animals undergoing domestication, Appl. Anim. Behav. Sci., 65, 245-271, 1999.

Price, E. O.: Neurophysiological approaches to the study of behavior genetics, in: Principles and applications of domestic animal behavior, edited by: Price, E. O., CABI, Wallingfort et al., UK, 21-22, 2008.

Raussi, S.: Human-cattle interactions in group housing, Appl. Anim. Behav. Sci., 80, 245-262, 2003.

Réale, D., Reader, S. M., Sol, D., McDougall, P. T., and Dingemanse, N. J.: Integrating animal temperament within ecology and evolution, Biol. Rev., 82, 291-318, 2007.

Reaume, C. J. and Sokolowski, M. B.: cGMP-Dependent Protein Kinase as a Modifier of Behaviour, Handbook of Experimental Pharmacology, 191, 423-443, 2009.

Reiner, G., Köhler, F., Berge, T., Fischer, R., Hübner-Weitz, K., Scholl, J., and Willems, H.: Mapping of quantitative trait loci affecting behaviour in swine, Anim. Genet., 40, 366-376, 2009.

Rupp, R. and Boichard, D.: Genetic Parameters for Clinical Mastitis, Somatic Cell Score, Production, Udder Type Traits, and Milking Ease in First Lactation Holsteins, J. Dairy Sci., 82, 2198 2204, 1999.

Rushen, J., Munksgaard, L., Marnet, P. G., and DePassillé, A. M.: Human contact and the effects of acute stress on cows at milking, Appl. Anim. Behav. Sci., 73, 1-14, 2001.

Sant'Anna, A. C., Paranhos da Costa, M. J. R., Baldi, F., and Albuquerque, L. G.: Genetic variability for temperament indicators of Nellore cattle, J. Anim. Sci., 91, 3532-3537, 2013.

Schmidtz, B. H., Buchanan, F. C., Plante, Y., and Schmutz, S. M.: Linkage mapping of the tyrosinase gene to bovine chromosome 29, Anim. Genet., 32, 119-120, 2001. 
Schmutz, S. M., Stookey, J. M., Winkelman-Sim, D. C., Waltz, C. S., Plante, Y., and Buchanan, F. C.: A QTL Study of Cattle Behavioral Traits in Embryo Transfer Families, J. Hered., 92, 290292, 2001.

Schrooten, C., Bovenhuis, H., Coppieters, W., and Van Arendonk, J. A. M.: Whole Genome Scan to Detect Quantitative Trait Loci for Conformation and Functional Traits in Dairy Cattle, J. Dairy Sci., 83, 795-806, 2000.

Schütz, K. E., Hawke, M., Waas, J. R., McLeay, L. M., Bokkers, E. A. M., van Reenen, C. G., Webster, J. R., and Stewart, M.: Effects of human handling during early rearing on the behaviour of dairy calves, Anim. Welfare, 21, 19-26, 2012.

Schwartzkopf-Genswein, K. S., Shah, M. A., Church, J. S., Haley, D. B., Janzen, K., Truong, G., Atkins, R. P., and Crowe, T. G.: A comparison of commonly used and novel electronic techniques for evaluating cattle temperament, Can. J. Anim. Sci., 92, 21-31, 2012.

Sewalem, A., Miglior, F., and Kistemaker, G. J.: Short communication: Genetic parameters of milking temperament and milking speed in Canadian Holsteins, J. Dairy Sci., 94, 512-516, 2011.

Shih, J. C., Chen, K., and Ridd, M. J.: Monoamine oxidase: From genes to behavior, Annu. Rev. Neurosci., 22, 197-217, 1999.

Spelman, R. J., Huisman, A. E., Singireddy, S. R., Coppieters, R. J., Arranz, J., Georges, M., and Garrick, D. J.: Quantitative Trait Loci Analysis on 17 Nonproduction Traits in the New Zealand Dairy Population, J. Dairy Sci., 82, 2514-2516, 1999.

Sutherland, M. A., Rogers, A. R., and Verkerk, G. A.: The effect of temperament and responsiveness towards humans on the behavior, physiology and milk production of multi-parous dairy cows in a familiar and novel milking environment, Physiol. Behav., 107, 329-337, 2012.

Van Reenen, C. G., Van der Werf, J. T. N., Bruckmaier, R. M., Hopster, H., Engel, B., Noordhuizen, J. P. T. M., and Blokhuis, H. J.: Individual Differences in Behavioral and Physiological Responsiveness of Primiparous Dairy Cows to Machine Milking, J. Dairy Sci., 85, 2551-2561, 2002.
Veissier, I., Aubert, A., and Boissy, A.: Animal welfare: A result of animal background and perception of its environment, Anim. Front., 2, 7-15, 2012.

Vetters, M. D. D., Engle, T. E., Ahola, J. K., and Grandin, T.: Comparison of flight speed and exit score as measurements of temperament in beef cattle, J. Anim. Sci., 91, 374-381, 2013.

Visscher, P. M. and Goddard, M. E.: Genetic Parameters for Milk Yield, Survival, Workability, and Type Traits for Australian Dairy Cattle, J. Dairy Sci., 78, 205-220, 1995.

Voisinet, B. D., Grandin, T., Tatum, J. D., O'Connor, S. F., and Struthers, J. J.: Feedlot cattle with calm temperaments have higher average daily gains than cattle with excitable temperaments, J. Anim. Sci., 75, 892-896, 1997.

Von Keyserlingk, M. A. G., Rushen, J., de Passillé, A. M., and Weary, D. M.: Invited review: The welfare of dairy cattle-Key concepts and the role of science, J. Dairy Sci., 92, 4101-4111, 2009.

Waiblinger, S., Menke, C., and Fölsch, D. W.: Influences on the avoidance and approach behaviour of dairy cows towards humans on 35 farms, Appl. Anim. Behav. Sci., 84, 23-39, 2003.

Watts, J. M., Stookey, J. M., Schmutz, S. M., and Waltz, C. S.: Variability in vocal and behavioural responses to visual isolation between full-sibling families of beef calves, Appl. Anim. Behav. Sci., 70, 255-273, 2001 .

Wegenhoft, M. A.: Locating quantitative trait loci associated with disposition in cattle, Senior honors thesis, Texas A\&M University, College Station, TX, USA, 2005.

Welfare Quality ${ }^{\circledR}$ : Welfare Quality ${ }^{\circledR}$ assessment protocol for cattle, Welfare Quality ${ }^{\circledR}$ Consortium, Lelystad, Netherlands, 2009. 